\title{
Lighter serum copper isotopic composition in patients with early non-alcoholic fatty liver disease
}

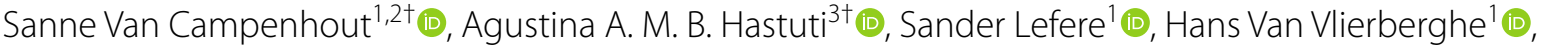 \\ Frank Vanhaecke ${ }^{3}$ (D) Marta Costas-Rodríguez ${ }^{3^{*}+}$ (i) and Lindsey Devisscher ${ }^{2^{*+}+}$ (D)
}

\begin{abstract}
Objective: The occurrence of non-alcoholic fatty liver disease (NAFLD) is globally increasing. To challenge the current incidence of NAFLD, non-invasive markers that could identify patients at risk or monitor disease progression are an important need. Copper intake and organ copper concentrations have earlier been linked to NAFLD progression, but serum copper does not adequately represent the disease state. Cu atoms occur under the form of two stable isotopes, ${ }^{63} \mathrm{Cu}$ and ${ }^{65} \mathrm{Cu}$, and the ratio of both (expressed as $\delta^{65} \mathrm{Cu}$, in \%) in blood serum has been shown to be altered in chronic liver disease. To assess whether the $\mathrm{Cu}$ isotope ratio might predict disease occurrence and progression of NAFLD, the serum Cu isotopic composition of patients with different stages of NAFLD was determined.

Results: Our results showed that serum $\delta^{65} \mathrm{Cu}$ values were lower in NAFLD patients, already at the level of simple steatosis, and remained stable during further disease progression. ROC analysis shows an almost perfect diagnostic ability of serum $\delta^{65} \mathrm{Cu}$ values for NAFLD, but no discrimination between different severity degrees could be made. Therefore, the serum $\mathrm{Cu}$ isotopic composition might show potential for early diagnosis of NAFLD patients.
\end{abstract}

Keywords: Liver steatosis, Non-alcoholic steatohepatitis, Cu isotopes, Multi collector inductively coupled plasma mass spectrometry

\section{Introduction}

Non-alcoholic fatty liver disease (NAFLD) is the most common liver disease with a global current prevalence of $24 \%$ [1]. In the past two decades, its incidence has

\footnotetext{
*Correspondence: marta.costasrodriguez@UGent.be; lindsey. devisscher@UGent.be

†Sanne Van Campenhout and Agustina A. M. B. Hastuti contributed equally to this work

${ }^{\dagger}$ Marta Costas-Rodríguez and Lindsey Devisscher contributed equally to this work

${ }^{2}$ Department of Basic and Applied Medical Sciences-Gut Liver Immunopharmacology Unit, Ghent University, Corneel Heymanslaan 10 entrance 36-floor 3, 9000 Ghent, Belgium

${ }^{3}$ Department of Chemistry, Atomic and Mass Spectrometry-A\&MS Research Unit, Ghent University, Campus Sterre, Krijgslaan 281-S12, 9000 Ghent, Belgium

Full list of author information is available at the end of the article
}

increased about fivefold, especially in young adults [2]. NAFLD can range from simple hepatic steatosis (fat accumulation, non-alcoholic fatty liver, NAFL) to liver inflammation (non-alcoholic steatohepatitis, NASH), which can evolve to liver fibrosis with varying degree of liver dysfunction [3]. Since patients with steatohepatitis are at increased risk of fibrosis development and might even develop hepatocellular carcinoma (HCC), and no pharmacological option for any stage of NAFLD is available so far, it is of interest to detect patients early in disease progression.

Recently, there has been a growing interest in high-precision $\mathrm{Cu}$ isotopic analysis, i.e. evaluating the ${ }^{65} \mathrm{Cu} /{ }^{63} \mathrm{Cu}$ ratio (expressed as $\delta^{65} \mathrm{Cu}$, in \%), as a diagnostic and prognostic tool for liver disease [4-7]. ${ }^{63} \mathrm{Cu}$ and ${ }^{65} \mathrm{Cu}$ are the two stable $\mathrm{Cu}$ isotopes that occur naturally, showing

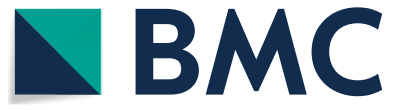

(c) The Author(s) 2020. This article is licensed under a Creative Commons Attribution 4.0 International License, which permits use, sharing, adaptation, distribution and reproduction in any medium or format, as long as you give appropriate credit to the original author(s) and the source, provide a link to the Creative Commons licence, and indicate if changes were made. The images or other third party material in this article are included in the article's Creative Commons licence, unless indicated otherwise in a credit line to the material. If material is not included in the article's Creative Commons licence and your intended use is not permitted by statutory regulation or exceeds the permitted use, you will need to obtain permission directly from the copyright holder. To view a copy of this licence, visit http://creativeco mmons.org/licenses/by/4.0/. The Creative Commons Public Domain Dedication waiver (http://creativecommons.org/publicdomain/ zero/1.0/) applies to the data made available in this article, unless otherwise stated in a credit line to the data. 
small, but systematic variations in their abundance ratio under certain disease conditions that can be reliably quantified [8-10]. It has been published recently that patients destined for bariatric surgery may show lower serum $\delta^{65} \mathrm{Cu}$ values [11]. Bariatric surgery is performed on morbidly obese patients to reduce food intake and obtain weight loss, and NAFLD is a prominent health risk in these patients. In the latter study, no liver biopsies were taken and no fibroscan was used to assess NAFLD in this patient cohort, and thus the initial status of liver disease was not known.

Therefore, we have investigated the diagnostic potential of serum $\delta^{65} \mathrm{Cu}$ values for different stages of NAFLD. We have collected serum from patients with biopsy-proven NAFLD with varying severity, and subjected these samples to high-precision $\mathrm{Cu}$ isotopic analysis via multicollector inductively coupled plasma-mass spectrometry (MC-ICP-MS).

\section{Main text}

Materials and methods

Patient cohort

A patient cohort of 10 NAFL and 14 NASH patients was recruited at the Ghent University Hospital within the context of a previous study (Table 1 for patient characteristics). Non-cirrhotic patients were scheduled for bariatric surgery. Specific clinical, biochemical, histological and/or radiographic criteria were used to exclude liver disease of other aetiologies, including cholestatic, alcohol-induced or drug-induced liver disease and viral or auto-immune hepatitis. All patients had biopsy-confirmed NAFLD and a negative history of alcohol abuse (average daily consumption of less than $20 \mathrm{~g} \mathrm{EtOH}$ ). Healthy controls from previous studies were used for comparison (Table 1) [11-13].

Table 1 Clinical characteristics of the patient cohort. Results are expressed as mean $\pm 95 \% \mathrm{Cl}$

\begin{tabular}{|c|c|c|c|}
\hline Characteristic & NAFL $(n=10)$ & NASH F0-F2 $(n=10)$ & NASH F4 $(n=4)$ \\
\hline Age (years) & $39.8 \pm 7.8$ & $47.5 \pm 8.9$ & $66.8 \pm 17.1$ \\
\hline Gender (M \%/F \%) & $10 / 90$ & $0 / 100$ & $100 / 0$ \\
\hline BMI $\left(\mathrm{kg} \mathrm{m}^{-2}\right)$ & $41.6 \pm 6.5$ & $42.7 \pm 7.2$ & $29.0 \pm 11.2$ \\
\hline Type 2 diabetes (\%) & 10 & 30 & 100 \\
\hline $\operatorname{AST}\left(U I^{-1}\right)$ & $23.3 \pm 4.2$ & $32.6 \pm 17.0$ & $31.8 \pm 21.5$ \\
\hline $\operatorname{ALT}\left(U I^{-1}\right)$ & $24.2 \pm 5.4$ & $39.4 \pm 24.3$ & $33.3 \pm 11.7$ \\
\hline $\mathrm{GGT}\left(U \mathrm{I}^{-1}\right)$ & $16.0 \pm 4.2$ & $51.5 \pm 27.8$ & $139.5 \pm 142.6$ \\
\hline Platelets $\left(10^{3} \mu^{-1}\right)$ & $274.5 \pm 29.9$ & $297.3 \pm 64.1$ & $133.8 \pm 87.0$ \\
\hline $\mathrm{Hb}\left(\mathrm{g} \mathrm{dl}^{-1}\right)$ & $13.2 \pm 0.6$ & $13.5 \pm 1.3$ & $12.4 \pm 3.4$ \\
\hline $\mathrm{HbA1c}(\%)$ & $5.6 \pm 0.3$ & $6.1 \pm 1.2$ & $6.2 \pm 1.8$ \\
\hline Total cholesterol $\left(\mathrm{mg} \mathrm{dl}^{-1}\right)$ & $186.8 \pm 21.1$ & $195.4 \pm 40.0$ & \\
\hline $\operatorname{LDL}\left(\mathrm{mg} \mathrm{dl}^{-1}\right)$ & $94.2 \pm 16.3$ & $103.2 \pm 21.0$ & \\
\hline $\mathrm{HDL}\left(\mathrm{mg} \mathrm{dl}^{-1}\right)$ & $66.3 \pm 11.8$ & $44.4 \pm 13.0$ & \\
\hline Triglycerides $\left(\mathrm{mg} \mathrm{dl}^{-1}\right)$ & $121.7 \pm 26.7$ & $219.9 \pm 76.5$ & \\
\hline Bilirubin $\left(\mathrm{mg} \mathrm{dl}^{-1}\right)$ & $0.4 \pm 0.1$ & $0.4 \pm 0.1$ & \\
\hline Fasting glucose $\left(\mathrm{mg} \mathrm{dl}^{-1}\right)$ & $98.2 \pm 18.5$ & $97.5 \pm 9.6$ & \\
\hline HOMA-IR & $4.4 \pm 2.4$ & $6.9 \pm 2.9$ & \\
\hline $\operatorname{Iron}\left(\mu \mathrm{g} \mathrm{dl^{-1 }}\right)$ & $76.6 \pm 26.4$ & $66.3 \pm 19.0$ & \\
\hline Transferrin $\left(\mathrm{mg} \mathrm{dl}^{-1}\right)$ & $2.9 \pm 0.3$ & $2.6 \pm 0.7$ & \\
\hline Ferritin $\left(\mu \mathrm{g}^{-1}\right)$ & $60.0 \pm 38.6$ & $155.1 \pm 122.3$ & \\
\hline Copper $\left(\mu \mathrm{g} \mathrm{dl} l^{-1}\right)$ & $137.4 \pm 38.4$ & $117.3 \pm 39.6$ & \\
\hline \multicolumn{4}{|l|}{ Control population } \\
\hline REF & Age, years & Gender (M\%/F\%) & $\mathrm{n}$ \\
\hline [11] & $43.8 \pm 8.5$ & $0 / 100$ & 10 \\
\hline [12] & $23-48$ & $100 / 0$ & 5 \\
\hline [13] & $51.57 \pm 6.9$ & $100 / 0$ & 7 \\
\hline
\end{tabular}

NAFL non-alcoholic fatty liver, NASH non-alcoholic steatohepatitis, BMI body mass index, AST aspartate aminotransferase, ALT alanine aminotransferase, GGT Y-glutamyltransferase, $\mathrm{Hb}$ Haemoglobin, HbA1c haemoglobin A1c, LDL low-density lipoprotein, HDL high-density lipoprotein, HOMA-IR Homeostasis Model Assessment Insulin Resistance 


\section{Clinical evaluation}

Anthropometric measurements of all patients were taken and the body mass index (BMI) was calculated as body weight $/$ height $^{2}\left(\mathrm{~kg} \mathrm{~m}^{-2}\right)$. Blood samples from patients were collected, centrifuged (10 $\left.\mathrm{min}, 4{ }^{\circ} \mathrm{C}, 350 \mathrm{~g}\right)$, and serum was stored at $-80^{\circ} \mathrm{C}$ until analysis. Thawed serum was analysed for the levels of aspartate aminotransferase (AST), alanine aminotransferase (ALT), $\gamma$-glutamyl transpeptidase (GGT), bilirubin, haemoglobin, triglycerides, high-density lipoprotein (HDL) cholesterol, low-density lipoprotein (LDL) cholesterol, total serum cholesterol, fasting glucose, haemoglobin A1c (HbA1c) and insulin and complete blood count. Insulin resistance was estimated by the homeostasis model assessment-insulin resistance (HOMA-IR) [14], and the presence of diabetes mellitus (according to the American Diabetes Association criteria [15]) was evaluated. In addition, iron, transferrin, ferritin and copper serum levels were determined.

Formalin-fixed liver biopsies were routinely processed and stained with haematoxylin and eosin, and Masson's trichrome. All biopsies were blinded and evaluated by an experienced pathologist according to the NASH clinical research network scoring system [16].

\section{Serum isotopic analysis}

Serum samples $(400 \mu \mathrm{L})$, were thawed and digested in perfluoroalkoxy (PFA) digestion vessels (Savillex, USA) with a $2: 1 \mathrm{v} / \mathrm{v}$ mixture of $14 \mathrm{M}$ pro analysis $\mathrm{HNO}_{3}$ (Chem-lab, Belgium and additionally purified by means of sub-boiling distillation) and $9.8 \mathrm{M} \mathrm{H}_{2} \mathrm{O}_{2}$ (SigmaAldrich, Belgium). The digestion was performed at $110{ }^{\circ} \mathrm{C}$ for $18 \mathrm{~h}$. The digest was then dried at $90{ }^{\circ} \mathrm{C}$ and the solid residue was re-dissolved in $5 \mathrm{~mL}$ of $8 \mathrm{M}$ Optima ${ }^{\mathrm{TM}}$ grade $\mathrm{HCl}$ (Fisher Chemical, UK) and $0.001 \% \mathrm{H}_{2} \mathrm{O}_{2}$ to ensure that $\mathrm{Cu}$ is present in its $\mathrm{Cu}(\mathrm{II})$ oxidation state.

$\mathrm{Cu}$ was isolated by anion exchange chromatography using $1 \mathrm{~mL}$ of AG-MP-1 resin (Bio-Rad Laboratories, CA, USA) [12]. Two column passes ensure sufficient purity, while a quantitative recovery avoids potential on-column isotope fractionation effects from affecting the final $\mathrm{Cu}$ isotope ratio results. The purified $\mathrm{Cu}$ fractions thus obtained were dried at $90{ }^{\circ} \mathrm{C}$ and the residue was re-dissolved in $1 \mathrm{~mL}$ of $14 \mathrm{M} \mathrm{HNO}_{3}$. This was done twice to fully remove remaining chlorine. Finally, the $\mathrm{Cu}$ fractions were re-dissolved in $0.42 \mathrm{M} \mathrm{HNO}_{3}$ for further elemental and isotopic analysis. Ultra-pure water (resistivity>18.2 $\mathrm{M} \Omega \mathrm{cm}$ ) was used throughout this study (Milli-Q Element water purification system, Millipore, France). All sample manipulations were performed in a class-10 clean room.

$\mathrm{Cu}$ isotope ratio measurements were performed using a Neptune MC-ICP-MS instrument (Thermo Scientific,
Germany), as described elsewhere [5]. Samples were measured in sample-standard bracketing (SSB) sequence using a solution of NIST SRM $976 \mathrm{Cu}$ isotopic reference material (NIST, USA) as external standard. $\mathrm{Cu}$ concentrations in samples and standard were matched within $\pm 10 \%$. The mass bias was corrected for using a combination of internal standardisation using $\mathrm{Ga}$ as internal standard, relying on the revised Russell's law as described by Baxter et al. [17], and external correction in an SSB approach. The $\mathrm{Cu}$ isotope ratio is expressed in delta notation as $\delta^{65} \mathrm{Cu}(\%)$, calculated as indicated in Eq. 1:

$$
\delta^{65} C u_{\text {sample }}=\left(\frac{{ }^{65} \mathrm{Cu} /{ }^{63} \mathrm{Cu} \text { sample }}{{ }^{65} \mathrm{Cu} /{ }^{63} \mathrm{Cu}}-1\right) \times 1000
$$

$\mathrm{A} \mathrm{Cu}$ in-house standard (Inorganic Ventures, the Netherlands) was measured every five samples to monitor the quality of the isotope ratio data. The $\mathrm{Cu}$ isotope ratio obtained for the in-house QC sample in this work was $\delta^{65} \mathrm{Cu}=0.223 \pm 0.009$ (sd, $\mathrm{n}=9$ ), which corresponds well with the value obtained in our previous study [12].

\section{Statistics}

Statistical analysis was performed using Graphpad Prism (Graphpad Software Inc., San Diego, California) and SPSS Statistics 25 (IBM Corp., USA). Kruskall-Wallis and Dunn's multiple comparisons test were used to compare groups and Receiver Operating Characteristic (ROC) analysis was performed. Spearman's rank correlation coefficient was used to evaluate potential relationships between biochemical parameters and the $\mathrm{Cu}$ isotopic composition within the NAFLD population. P-values were two-sided and considered significant when lower than 0.05 .

\section{Results}

In NAFLD patients, serum $\delta^{65} \mathrm{Cu}$ values were lower than in healthy controls (Fig. 1a), even at the level of simple steatosis (NAFL) $(\mathrm{p} \leq 0.04)$, and remained stable during further disease progression (Fig. 1a). More specifically, average serum $\delta^{65} \mathrm{Cu}$ values were lower by $0.57 \%$ o $\pm 0.35 \%$ o (sd), $0.71 \pm 0.47 \%$ o (sd), and $0.76 \pm 0.51 \%$ o (sd) in NAFL patients, NASH patients with F0-F2 fibrosis, and NASH patients with cirrhosis (F4), respectively. This suggests that the lower serum $\delta^{65} \mathrm{Cu}$ value is an early event in NAFLD and is thus already present before the onset of liver inflammation.

Importantly, ROC analysis shows an almost complete (AUC $=0.9896, \mathrm{p}<0.0001)$ diagnostic ability of serum $\delta^{65} \mathrm{Cu}$ values for NAFLD patients (Fig. 1b). In contrast, no further discrimination can be made between NAFL 

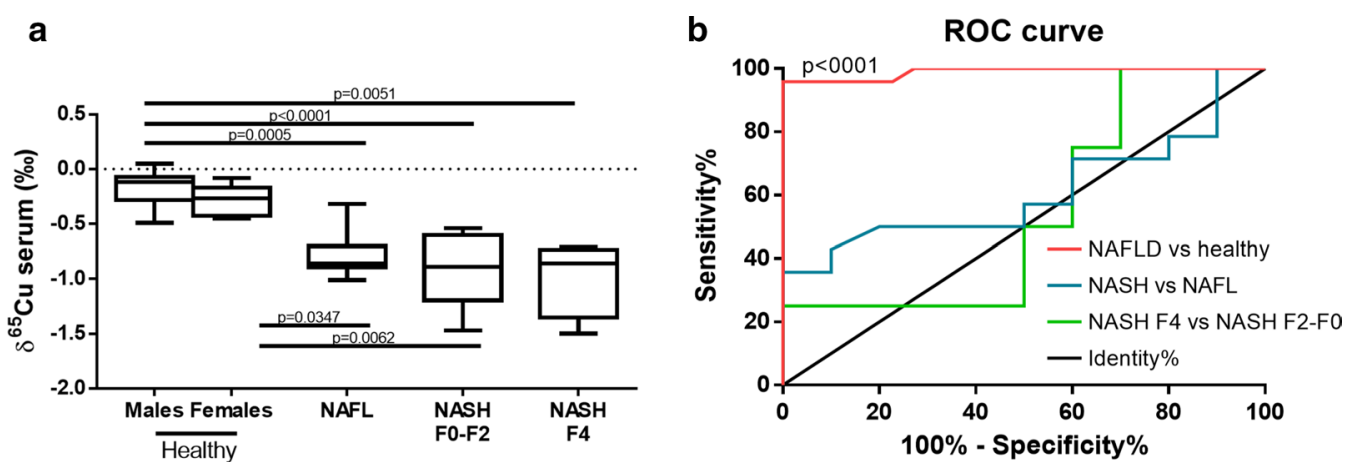

Fig. 1 Serum $\delta^{65} \mathrm{Cu}$ changes in non-alcoholic fatty liver disease (NAFLD). a Serum $\delta^{65} \mathrm{Cu}$ values for different stages of NAFLD. Statistical analysis was performed by Kruskal-Wallis and Dunn's multiple comparisons test. b Receiver Operating Characteristic (ROC) analysis of serum $\delta^{65} \mathrm{Cu}$ values. P-values were two-sided and considered significant when lower than 0.05. F0-F4 refers to the corresponding fibrosis stage. Healthy males: $\mathrm{n}=12$, healthy females: $n=10$. Non-alcoholic fatty liver (NAFL): $n=10$. Non-alcoholic steatohepatitis (NASH) FO-F2: $n=10$. NASH F4: $n=4$

and NASH patients $(\mathrm{AUC}=0.6107, \mathrm{p}=0.36)$ or between NASH patients with F0-F2 fibrosis and with cirrhosis (F4) $(\mathrm{AUC}=0.5500, \mathrm{p}=0.78)$. In addition, no relevant or significant correlations between clinical parameters and serum $\delta^{65} \mathrm{Cu}$ values within the NAFLD patient cohort were observed $(\max |\rho|=0.22$, Table 2$)$.

\section{Discussion}

Lower serum $\delta^{65} \mathrm{Cu}$ values have been described in patients with end stage liver disease (cirrhosis), arising from several aetiologies, in cancer patients, and in patients with Wilson's disease [4-8]. In addition, we have shown a whole-body enrichment of the light ${ }^{63} \mathrm{Cu}$ isotope in an experimental model for secondary biliary fibrosis [18]. Our data align those previous results and further elaborate on serum $\delta^{65} \mathrm{Cu}$ values within different NAFLD stages. In agreement with previously published data of a bariatric cohort [11], serum $\delta^{65} \mathrm{Cu}$ values were lower in NAFLD patients. The variation of serum $\delta^{65} \mathrm{Cu}$ values in different stages of NAFLD had not been investigated thus far, and we show that, already at the level of simple steatosis, serum $\delta^{65} \mathrm{Cu}$ values are lower, and remain stable during further disease progression. We highlight lower serum $\delta^{65} \mathrm{Cu}$ values as diagnostic tool for NAFLD, irrespective of disease progression. Currently, patients are screened for steatosis by non-invasive imaging techniques (such as ultrasound or the controlled attenuation parameter), which require patients to go to a hospital or center where this equipment is available [19]. In addition, the general practitioner can take blood samples for serum biomarker analysis (such as the fatty liver index or the SteatoTest). However, the diagnostic ability of these biomarkers for steatosis (AUROC ranging from 0.73$0.86)$ can still be improved [19]. Our results show potential for serum $\delta^{65} \mathrm{Cu}$ to exceed the diagnostic ability of
Table 2 Spearman's correlation analysis between serum $\delta^{65} \mathrm{Cu}$ levels and clinical parameters within the NAFLD patient cohort

\begin{tabular}{|c|c|c|c|}
\hline & Spearman's $\rho$ & $\mathbf{p}$ & $\mathbf{n}$ \\
\hline BMI $\left(\mathrm{kg} \mathrm{m}^{-2}\right)$ & 0.03 & 0.89 & 24 \\
\hline Steatosis on liver biopsy & -0.22 & 0.34 & 21 \\
\hline Ballooning on liver biopsy & -0.20 & 0.37 & 21 \\
\hline Inflammation on liver biopsy & -0.09 & 0.71 & 21 \\
\hline NAS on liver biopsy & -0.19 & 0.42 & 21 \\
\hline Fibrosis on liver biopsy & -0.13 & 0.54 & 24 \\
\hline Presence of NASH (yes/no) & -0.19 & 0.38 & 24 \\
\hline $\operatorname{AST}\left(\mathrm{Ul}^{-1}\right)$ & 0.25 & 0.23 & 24 \\
\hline $\mathrm{ALT}\left(\mathrm{Ul}^{-1}\right)$ & 0.03 & 0.89 & 24 \\
\hline $\mathrm{GGT}\left(\mathrm{UI}^{-1}\right)$ & -0.05 & 0.81 & 24 \\
\hline Bilirubin (mg dl ${ }^{-1}$ ) & -0.07 & 0.77 & 20 \\
\hline Glucose $\left(\mathrm{mg} \mathrm{dl}^{-1}\right)$ & 0.24 & 0.30 & 20 \\
\hline HOMA-IR & 0.26 & 0.27 & 20 \\
\hline HbA1c (\%) & 0.09 & 0.70 & 23 \\
\hline Diabetes (yes/no) & 0.19 & 0.39 & 24 \\
\hline Cholesterol (mg dl $\left.{ }^{-1}\right)$ & 0.22 & 0.39 & 17 \\
\hline $\mathrm{HDL}\left(\mathrm{mg} \mathrm{dl}^{-1}\right)$ & -0.10 & 0.71 & 17 \\
\hline $\mathrm{LDL}\left(\mathrm{mg} \mathrm{dl^{-1 } )}\right.$ & -0.06 & 0.80 & 19 \\
\hline Triglycerides (mg dl ${ }^{-1}$ ) & -0.16 & 0.50 & 20 \\
\hline Ferritin $\left(\left.\mu g\right|^{-1}\right)$ & 0.24 & 0.33 & 19 \\
\hline Copper $\left(\mu \mathrm{g} \mathrm{dl^{-1 }}\right)$ & 0.10 & 0.69 & 18 \\
\hline Transferrin $\left(\mathrm{mg} \mathrm{dl}^{-1}\right)$ & -0.03 & 0.91 & 19 \\
\hline Iron $\left(\mu \mathrm{g} \mathrm{dl}^{-1}\right)$ & -0.03 & 0.92 & 19 \\
\hline
\end{tabular}

NAFL non-alcoholic fatty liver, NASH: non-alcoholic steatohepatitis, BMI: body mass index, AST aspartate aminotransferase, ALT alanine aminotransferase, GGT Y-glutamyltransferase, $\mathrm{Hb}$ Haemoglobin, $\mathrm{HbA1}$ c haemoglobin A1c, LDL lowdensity lipoprotein, HDL high-density lipoprotein, HOMA-IR Homeostasis Model Assessment Insulin Resistance, NAS NAFLD activity score 
current serum biomarkers, and to diagnose patients with early NAFLD, a population that would benefit from early notification to prevent progression to $\mathrm{NASH}$, for which no medical therapy is available so far.

\section{Limitations}

Although our patient population covers different stages of NAFLD, no obese patients without NAFLD were included. These patients could have revealed additional information about the initial stage and cause of the lower serum $\delta^{65} \mathrm{Cu}$ values. In addition, both genders were not equally represented in the different NAFLD stages. However, when we compare male and female healthy controls, the difference between average serum $\delta^{65} \mathrm{Cu}$ values was much smaller $(0.12 \%$ ) than the observed disease effects $(0.57-0.76 \%$ ) and not significant (Fig. 1a). A larger patient cohort could have also allowed to evaluate assay reproducibility and sensitivity. Nevertheless, serum $\delta^{65} \mathrm{Cu}$ values have previously been shown to be reproducible in healthy controls [11-13], so that these results seem highly reliable.

\begin{abstract}
Abbreviations
ALT: Alanine aminotransferase; AST: Aspartate aminotransferase; BMI: Body mass index; GGT: $\gamma$-Glutamyltransferase; Hb: Haemoglobin; HbA1c: Haemoglobin A1c; HCC: Hepatocellular carcinoma; HDL: High-density lipoprotein; HOMA-IR: Homeostasis Model Assessment Insulin Resistance; LDL: Lowdensity lipoprotein; NASH: Non-alcoholic steatohepatitis; NAFL: Non-alcoholic fatty liver; NAFLD: Non-alcoholic fatty liver disease.
\end{abstract}

\section{Acknowledgements}

Not applicable.

\section{Authors' contributions}

SVC, AAMBH, LD, HV, FV and MCR conceptualized and designed the experiment and methodology. SVC and SL performed sample collection, data acquisition and analysis under the supervision of LD and HVV. AH performed the MC-ICP-MS Cu isotopic analysis under supervision of MCR and FV. SVC, AAMBH and LD wrote the manuscript. All authors contributed to data interpretation and to the final manuscript.

\section{Funding}

The Special Research Fund of Ghent University BOF-UGent is acknowledged for financial support under the form of an interdisciplinary research project (IOP). MCR thanks FWO-Vlaanderen for her post-doctoral grant. HVV is an FWO senior researcher.

\section{Availability of data and materials}

The datasets used and/or analysed during the current study are available from the corresponding authors on reasonable request.

\section{Ethics approval and consent to participate}

The study was approved by the Ghent University Hospital Ethical Committee and all participants gave their written informed consent at Ghent University Hospital.

\section{Consent for publication}

Not applicable.

\section{Competing interests}

The authors declare that they have no competing interests.

\section{Author details}

${ }^{1}$ Department of Internal Medicine and Pediatrics-Hepatology Research Unit, Ghent University, Corneel Heymanslaan 10 entrance 12-floor 1, 9000 Ghent, Belgium. ${ }^{2}$ Department of Basic and Applied Medical Sciences-Gut Liver Immunopharmacology Unit, Ghent University, Corneel Heymanslaan 10 entrance 36-floor 3, 9000 Ghent, Belgium. ${ }^{3}$ Department of Chemistry, Atomic and Mass Spectrometry-A\&MS Research Unit, Ghent University, Campus Sterre, Krijgslaan 281-S12, 9000 Ghent, Belgium.

Received: 26 March 2020 Accepted: 9 April 2020

Published online: 19 April 2020

\section{References}

1. Younossi Z, Anstee QM, Marietti M, Hardy T, Henry L, Eslam M, et al. Global burden of NAFLD and NASH: trends, predictions, risk factors and prevention. Nat Rev Gastroenterol Hepatol. 2018;15:11-20. https://doi. org/10.1038/nrgastro.2017.109.

2. Allen AM, Therneau TM, Larson JJ, Coward A, Somers VK, Kamath PS. Nonalcoholic fatty liver disease incidence and impact on metabolic burden and death: a 20 year-community study. Hepatology. 2018;67:1726-36. https://doi.org/10.1002/hep.29546.

3. Calzadilla Bertot $L$, Adams LA. The natural course of non-alcoholic fatty liver disease. Int J Mol Sci. 2016. https://doi.org/10.3390/ijms17050774.

4. Costas-Rodríguez M, Anoshkina Y, Lauwens S, Van Vlierberghe $H$, Delanghe J, Vanhaecke F. Isotopic analysis of Cu in blood serum by multi-collector ICP-mass spectrometry: a new approach for the diagnosis and prognosis of liver cirrhosis? Metallomics. 2015;7:491-8. https://doi. org/10.1039/C4MT00319E.

5. Lauwens S, Costas-Rodríguez M, Van Vlierberghe H, Vanhaecke F. Cu isotopic signature in blood serum of liver transplant patients: a follow-up study. Sci Rep. 2016;6:30683. https://doi.org/10.1038/srep30683.

6. Balter V, Nogueira da Costa A, Bondanese VP, Jaouen K, Lamboux A, Sangrajrang $S$, et al. Natural variations of copper and sulfur stable isotopes in blood of hepatocellular carcinoma patients. Proc Natl Acad Sci. 2015;112:982-5. https://doi.org/10.1073/pnas.1415151112.

7. Aramendía M, Rello L, Resano M, Vanhaecke F. Isotopic analysis of Cu in serum samples for diagnosis of Wilson's disease: a pilot study. J Anal At Spectrom. 2013;28:675. https://doi.org/10.1039/c3ja30349g.

8. Télouk P, Puisieux A, Fujii T, Balter V, Bondanese VP, Morel A-P, et al. Copper isotope effect in serum of cancer patients. A pilot study. Metallomics. 2015;7:299-308. https://doi.org/10.1039/C4MT00269E.

9. Costas-Rodríguez M, Delanghe J, Vanhaecke F. High-precision isotopic analysis of essential mineral elements in biomedicine: natural isotope ratio variations as potential diagnostic and/or prognostic markers. TrAC Trends Anal Chem. 2016;76:182-93. https://doi.org/10.1016/j. trac.2015.10.008.

10. Albarede F, Télouk P, Balter V, Bondanese VP, Albalat E, Oger P, et al. Medical applications of $\mathrm{Cu}, \mathrm{Zn}$, and S isotope effects. Metallomics. 2016;8:1056-70. https://doi.org/10.1039/C5MT00316D.

11. Hastuti AAMB, Costas-Rodríguez M, Anoshkina Y, Parnall T, Madura JA, Vanhaecke F. High-precision isotopic analysis of serum and whole blood $\mathrm{Cu}, \mathrm{Fe}$ and $\mathrm{Zn}$ to assess possible homeostasis alterations due to bariatric surgery. Anal Bioanal Chem. 2020;412:727-38. https://doi.org/10.1007/ s00216-019-02291-2.

12. Lauwens $S$, Costas-Rodríguez M, Van Vlierberghe H, Vanhaecke F. Highprecision isotopic analysis of Cu in blood serum via multi-collector ICP-mass spectrometry for clinical investigation: steps towards improved robustness and higher sample throughput. J Anal At Spectrom. 2017;32:597-608. https://doi.org/10.1039/C6JA00433D.

13. Lauwens S, Costas-Rodríguez M, Delanghe J, Van Vlierberghe H, Vanhaecke F. Quantification and isotopic analysis of bulk and of exchangeable and ultrafiltrable serum copper in healthy and alcoholic cirrhosis subjects. Talanta. 2018;189:332-8. https://doi.org/10.1016/j.talan ta.2018.07.011.

14. Matthews DR, Hosker JP, Rudenski AS, Naylor BA, Treacher DF, Turner RC. Homeostasis model assessment: insulin resistance and?-cell function from fasting plasma glucose and insulin concentrations in man. Diabetologia. 1985;28:412-9. https://doi.org/10.1007/BF00280883. 
15. Model CC. Standards of medical care in diabetes-2015 abridged for primary care providers. Clin Diabetes. 2015;33:97-111. https://doi. org/10.2337/diaclin.33.2.97

16. Kleiner DE, Brunt EM, Van Natta M, Behling C, Contos MJ, Cummings $\mathrm{OW}$, et al. Design and validation of a histological scoring system for nonalcoholic fatty liver disease. Hepatology. 2005;41:1313-21. https://doi. org/10.1002/hep.20701

17. Baxter DC, Rodushkin I, Engström E, Malinovsky D. Revised exponential model for mass bias correction using an internal standard for isotope abundance ratio measurements by multi-collector inductively coupled plasma mass spectrometry. J Anal At Spectrom. 2006;21:427. https://doi. org/10.1039/b517457k

18. Costas-Rodríguez M, Van Campenhout $\mathrm{S}$, Hastuti AAMB, Devisscher L, Van Vlierberghe $H$, Vanhaecke F. Body distribution of stable copper isotopes during the progression of cholestatic liver disease induced by common bile duct ligation in mice. Metallomics. 2019. https://doi.org/10.1039/ C8MT00362A.

19. European Association for the Study of the Liver (EASL). EASL-EASD-EASO Clinical Practice Guidelines for the management of non-alcoholic fatty liver disease. Diabetologia. 2016;59:1121-40. https://doi.org/10.1007/ s00125-016-3902-y.

\section{Publisher's Note}

Springer Nature remains neutral with regard to jurisdictional claims in published maps and institutional affiliations.
Ready to submit your research? Choose BMC and benefit from:

- fast, convenient online submission

- thorough peer review by experienced researchers in your field

- rapid publication on acceptance

- support for research data, including large and complex data types

- gold Open Access which fosters wider collaboration and increased citations

- maximum visibility for your research: over $100 \mathrm{M}$ website views per year

At BMC, research is always in progress.

Learn more biomedcentral.com/submissions 